\title{
Petrophysical Characteristics of Coastal Swamp Depobelt Reservoir in the Niger Delta Using Well-Log Data
}

\author{
Dieokuma Tamunosiki ${ }^{1}$, Gu Han Ming ${ }^{1}$ and Liping Wang ${ }^{1}$, Etim D. Uko ${ }^{2}$ and \\ Warmate Tamunonengiyeofori ${ }^{2}$ \\ ${ }^{1}$ Department of Geophysics and Geomatics, China University of Geosciences, 388 Lumo Road, Wuhan City, \\ Hubei Province 430074, P. R. China. \\ ${ }^{2}$ Department of Physics, Rivers State University of Science and Technology, P.M.B. 5080, Port Harcourt, \\ Nigeria.
}

\begin{abstract}
Sonic, gamma ray, density and resistivity logs in the onshore Coastal Swamps of the Niger Delta are used in the determination of some petrophysical properties of the reservoir in the Coastal Swamp Depobelt in the Niger Delta. The parameters investigated were porosity, velocities, shear and compressional velocities, and Poisson's ratio. The results of the analysis show that the reservoir is $66 \mathrm{~m}$ sandstone thick having porosity range of $0.21-0.39$ with average of 0.26 ; density ranges between 2.01 and 2.30 with average of $2.21 \mathrm{~g} / \mathrm{cc}$; Poisson's ratio range $0.33-0.45$ with 0.40 as average value; shear-wave velocity $V_{s}$ ranges from 718 to 1097 having average of $932.33 \mathrm{~m} / \mathrm{s}$, compressional-wave velocity $V_{p}$ ranges from 2110 to 2570 with average of $2230 \mathrm{~m} / \mathrm{s}, V_{p} / V_{s}$ ratio ranges $1.96-3.18$ with average value of 2.55 ; and Gamma-ray GR value ranges $62-105$ having average of $90 \mathrm{AP}$ and $V_{s} 718 \mathrm{~m} / \mathrm{s}$ are indicative fluid-filled reservoir. The results of this work can be used for well drilling and petroleum production programmes, and for civil engineering work in the area of study.
\end{abstract}

Keywords: Petrophysical properties, reservoir characterization, lithofacies, porosity, Poisson's ratio, compressional and shear velocities, Niger Delta

\section{INTRODUCTION}

On discovery of oil and gas, some of the key properties to evaluate are lithology, porosity, water saturation, permeability, density, compressional and shear velocities, Poisson's ratio, among others. These parameters when combined with geological and petrophysical data give a complete picture of the reservoir. To this effect, this research work aims at determining the reservoir geophysical and mechanical properties in the Coastal Swamp Depobelt in the Niger Delta. The petrophysical properties from the results of this work can be used to design drilling and production programmes while the mechanical properties can be applied in the design and construction of dams, roads, foundations for high-rise buildings and many other large construction projects in the area of study.

\section{GeOlOGy OF STUDY AREA}

The area of study is between longitudes $7^{\circ}$ to $8^{\circ} \mathrm{E}$, and latitudes $4^{\circ}$ to $4.5^{\circ} \mathrm{N}$ within Coastal Swamp Depobelt region of the Niger Delta (Figure 1). The structural configuration of the study area is a large simple rollover structure (Figure 2). The sedimentation type within the area is paralic sand and shale sequences. The shale sequences become more prevalent deeper down between 1930 and 2050 metres Sub Sea. This depth interval is equivalent to $1920-2800$ milliseconds respectively on the seismic section.

The entire Delta is composed of three major structural Formations: Akata, Agbada and Benin Formations (Figure 3). The Benin Formation is the upper alluvial coastal plain depositional environment of the Niger Delta Complex. It extends from the west Niger Delta across the entire Niger Delta area and to the south beyond the present coastline. The Benin Formation was deposited in a continental fluviatile environment and composed almost entirely of non-marine sandstone. Its lithology consists of coarse-grained sandstones, gravel lignite streaks and wood fragments with minor intercalation of shales. Benin Formation is of Miocene to younger age and has a variable thickness that exceeds $1820 \mathrm{~m}$. In the subsurface, it is of Oligocene age in the north becoming progressively younger southwards but ranges from Miocene to Recent as generally accepted. Very little hydrocarbon accumulation has been associated with this formation [1].

The Agbada Formation underlies the Benin Formation, and is the major petroleum-bearing unit. It was laid down in paralic brackish to marine fluviatile, coastal environments. In the lower Agbada Formation, shale and sandstone beds were deposited in equal proportions, however, the upper portion is mostly sand with only minor shale interbeds. It is made up mainly of alternating sandstone, silt and shale. The sandstones are poorly sorted, rounded to sub-rounded, slightly consolidated but majority are unconsolidated. The sandstones grade into shale in the lower part of the formation. Agbada Formation ranges in age from Eocene in the north to 
Pliocene in the south. The sandy parts of the formation are known to constitute the main hydrocarbon reservoirs of the delta oil fields and the shales constitute seals to the reservoirs. The thickness of the formation reaches a maximum of about 4500m [1]. Petroleum occurs throughout the Agbada Formation of the Niger Delta, however, several directional trends form an "oil-rich belt" having the largest field and lowest gas:oil ratio [2, 3, 4].

The Akata Formation is the lowest unit of the Niger Delta complex, and is of marine origin and is composed of thick shale sequences (potential source rock), turbidite sand (potential reservoirs in deep water), and minor amounts of clay and silt. It is composed of mainly shale with sandstones and siltstones locally interbedded. The Formation becomes shalier with depth. It is estimated that the formation is up to 7,000 meters thick in the central part of the delta [4]. The formation underlies the entire delta, and is typically overpressured. The Akata Formation outcrops offshore in diapirs along the continental slope, and onshore in the north east, where they are called Imo Shale. The age of the Akata Formation ranges from Eocene to Recent [1].

\section{MATERIALS AND METHODS}

\section{Determination of lithology and volume of mineralogy}

Gamma-ray log (Figure 4) was used to delineate the lithologies at the pre-determined depth intervals. The American Petroleum Institute (API) values ranges from sandstone line 0 to shale line 125 . As the signature of the log moves towards the higher values, the formation becomes shalier. The delineation approach enabled us to estimate and establish the lithological sequence of the formation of the study area.

To determine the ratio of sand to shale of the subsurface geology of the study area, Gamma ray log delineated into sections with two litho faces, namely, sandstones and shale. The gamma ray log reflects the shale content of sedimentary formations. Clean sandstones and carbonates normally exhibit a low level of natural radioactivity, while clay minerals and fluid particles in shales show higher levels of radioactivity due to adsorption of the heavy radioactive elements [5].

Clean sandstones were delineated as with log signatures increasing towards the sand-line that is low API unit ranging between 0 and 20 API units. For sandy-shales it ranges from 20 to 100 API units. While shales have API unit values of 100 and above with log signatures moving towards the shale line.

The percentages of sandstones and shales were estimated using Gamma ray logs, Figure 4. The API values indicate sand and shale domains. From the Header of the $\log$, the API values ranges from 0 to 125 . As the values increases, the formation lithology becomes shalier. This delineation approach enabled us to estimate the ratio of sand to shale and established the lithological sequence of the formation of the study area. Figure 4 shows sand/shale percentages at various depths. Gamma-ray API, density and porosity cross-plotted against depth (Figures 5 - 8) indicate a less-dense porous sandy formation in the depth region of 1864 and 1930m, while shaley-sand formation is at $1930-2050 \mathrm{~m}$.

\section{Determination of porosity}

It is generally accepted among geoscientists that porosity calculation from bulk density logs is more accurate $[6,7,8,9]$. To calculate the porosity, $\phi$, we use the rock matrix density, $\rho_{\text {ma }}$, the fluid density, $\rho_{\mathrm{f}}$, and the bulk density, $\rho_{\mathrm{b}}$. The average rock density in the sandstones research reports is $2.66 \mathrm{gcm}^{-3}$. The average rock density in the shales is $2.65 \mathrm{gcm}^{-3}$. The fluid density depends on whether the well encountered water or hydrocarbons. This was determined by the electrical resistivity log. The hydrocarbon density was calculated from composition and phase considerations, oil $=0.80 \mathrm{gcm}^{-3}$ and gas $=0.6 \mathrm{gcm}^{-3}$. The water density used was 1 $\mathrm{gcm}^{-3}$. Porosity was determined from the formula [10]:

$$
\phi_{\text {density }}=\frac{\rho_{m a}-\rho_{b}}{\rho_{m a}-\rho_{f}}
$$

where $\rho_{\mathrm{ma}}=$ matrix (or grain) density, $\rho_{\mathrm{f}}=$ fluid density and $\rho_{\mathrm{b}}=$ bulk density (as measured by the tool and hence includes porosity and grain density.

\section{Determination of Sonic Velocity}

This was based on the fact that, sonic transit time is directly related to the acoustic velocity which is a function of formation lithology and porosity. The sonic log is simply a recording of the time required for a sound wave to traverse one foot of formation known as interval transit time [5]. Sonic log is also a measure of a formation capacity to transmit sound waves. Geologically, this capacity varies with lithologies and rock texture, notably porosity, when the lithology is known [11]. This makes the sonic log very useful as a porosity log. Integrated sonic transit times are also useful in interpreting seismic records.

A sudden increase in transit time with depth indicates the presence of abnormal pressure. The sonic transit time values were obtained using the simple ratio method. The Sonic log velocities were crossed-checked with the correlative two-way-travel (TWT) seismic velocity (checkshots) data. 
The interval transit time values were picked at chosen depth interval. The acoustic velocities were obtained or computed by taking the inverse of the interval transit time $\Delta \mathrm{t}$.

$$
V_{P}=\frac{1}{\Delta t}\left(f t[\mu s]^{-1}\right)
$$

Poisson's ratio, $\sigma$, is defined in the relation as:

$$
\sigma=\frac{0.5\left(\frac{V_{p}}{V_{s}}\right)^{2}-1}{\left(\frac{V_{p}}{V_{s}}\right)^{2}-1}
$$

In the composite log (Figure 4), Poisson's ratio $(\sigma)$ and compressional wave velocity $\left(\mathrm{V}_{\mathrm{P}}\right)$ are given on the $\log$; using Equation 3 Shear wave velocity $\mathrm{V}_{\mathrm{s}}$ was computed.

\section{Determination of Permeability (K)}

Formation Factor for shaly sands $[12,13,14]$ :

$$
F=\frac{1.65}{\phi^{1.33}}
$$

Permeability (K) relates to Formation Factor [6]:

$$
K=\frac{\left(7.0 \times 10^{8}\right)}{F^{4.5}}
$$

\section{Determination of Water Saturation, $S_{w}$}

To calculate water saturation $S_{w}$ of un-invaded zone, the method used requires a water resistivity $R_{w}$ value at formation temperature calculated from the porosity and resistivity logs within clean water zone, using the inverse Archie method:

$$
R_{w}=\frac{\phi^{m} \times R_{t}}{a}
$$

where $R_{w}$ is the water resistivity at formation temperature, $\phi$ and $\mathrm{R}_{\mathrm{t}}$ are the total porosity and deep resistivity values in the water zone respectively. Tortuosity factor represented as " $\mathrm{a}$ " and " $\mathrm{m}$ " is the cementation exponent, usually 2 for sands [15]. In the water zone, saturation should be equal to 1 , as water resistivity $R_{w}$ at formation temperature is equal to $R_{w a}[16,17]$. We used $m=1.5, a=2$, and $R_{t}$ was read from the Log.

The Archie Equation relates water saturation $S_{\mathrm{w}}$ to formation water resistivity as follows:

$$
S_{w}^{n}=\frac{F \cdot R_{w}}{R_{t}}
$$

where

$$
\begin{aligned}
\mathrm{S}_{\mathrm{w}} & =\text { water saturation; } \\
\mathrm{n} & =\text { saturation exponent }=2 ; \\
S_{w} & =\sqrt{\frac{F \cdot R_{w}}{R_{t}}}
\end{aligned}
$$

Substituting for F from Equation (11), Equation (12) becomes:

$$
S_{w}=\sqrt{\frac{1.65 \times R_{w}}{\phi^{1.33} x R_{t}}}
$$

\section{IV.}

RESULTS AND DiSCUSSION

The results of the work are presented in Tables 1 and 2, and Figures $4-19$. Figure 4 shows the composite log sheet. To the right end of this figure are displayed side-by-side synthetic and real seismic traces in time (ms) with crest and troughs. The signatures of the logs and the seismic traces reveal that the reservoir is located between depth $1864 \mathrm{~m}$ and $2050 \mathrm{~m}$. Moreover, the data from gamma-ray, density and the P-wave logs show that depth $1864 \mathrm{~m}$ to $1930 \mathrm{~m}$ is gas-sand, highly porous saturated zone, which is indicative of the fluid accumulation zone of the reservoir. The shaley-sand portion of the reservoir falls within the depths 1930 and 2050m as shown Figure 5 sand/shale-depth cross-plot and Figure 6 the plot of Gamma-ray API values against depth. This zone with the circle indicates a porous sandy formation in the depth region of 1864 and 1930, while 
shaley-sand formation is at 1930-2050m. Figure 7 shows density-depth cross-plot while Figure 8 is a porositydepth cross-plot. The porosity plot against depth of Figure 8 shows a decrease in porosity with increasing depth but with a trend deviation in region of the reservoir from $1864 \mathrm{~m}$ to $2050 \mathrm{~m}$.

The computed values of the permeability are presented in Table 1 below. Figure 9 is a permeabilitydepth cross-plot. There is a normal linear decrease of permeability with an increase in depth, but within the reservoir $(1864-2050 \mathrm{~m})$ there is an increase of permeability with an increase in depth (Figure 9) as shown in the circled part of the depth-permeability cross-plot. This indicates a highly permeability zone with values ranging between 282.878 and $15,987.853 \mathrm{md}$. When permeability is cross-plotted against porosity, there is an exponential increase of permeability with porosity (Figure 10) showing that the reservoir is highly porous.

The computed values of water saturation are presented in Table 1 below. There is a linear decrease of water saturation with an increase in depth, but within the reservoir $(1864-2050 \mathrm{~m})$ there is an increase of water saturation with an increase in depth (Figure 11) as shown in the circled part of the depth-water saturation crossplot. Water saturation ranges between 0.761 and 0.806 . This indicates a highly water-saturated zone. When water saturation is cross-plotted against permeability, there is an exponential increase of permeability with water saturation (Figure 12) showing that the reservoir is highly permeable. There is a linear relationship between water saturation and porosity (Figure 13) showing that the reservoir is highly porous and permeable.

Figure 11 is water saturation-depth cross-plot; Figure 12 is permeability-water saturation cross-plot, while Figure 13 is porosity-water saturation cross-plots. From the signatures of these profiles, the reservoir is highly porous, permeable with high water saturation.

Figure 14 displaying $\mathrm{V}_{\mathrm{p}}$-depth cross-plot shows the linear variation of compressional wave velocity $\mathrm{V}_{\mathrm{p}}$ with depth. Figure 15 is a cross-plot of $\mathrm{V}_{\mathrm{p}}$ versus $\mathrm{V}_{\mathrm{s}}$. The plot of $\mathrm{P}$-wave velocity against $\mathrm{S}$-wave velocity shows an almost linear trend as presented by Figure 15 . Figure 15 is a cross-plot of $V_{p}$ against shear wave velocity $V_{s}$ for the sand and shaley sand sequences. The probable hydrocarbon-charged zone has $\mathrm{V}_{\mathrm{p}}$ ranging from 2110 to $2570 \mathrm{~m} / \mathrm{s}$ and $\mathrm{V}_{\mathrm{s}}$ from 873 to $1091 \mathrm{~m} / \mathrm{s}$. This work shows that there is a linear relationship between P-wave velocity and S-wave velocity for brine saturation. In the Gulf of Mexico, Castagna [18] established the Mudrock Line to be $\mathrm{Vp}=1.16 \mathrm{Vs}+1.36$ for velocity in $\mathrm{km} / \mathrm{s}$. From Figure 19 Mudrock Line for the study area is here established to be:

where velocity is in $\mathrm{km} / \mathrm{s}$.

$$
\mathrm{V}_{\mathrm{p}}=0.807 \mathrm{~V}_{\mathrm{s}}+1.600
$$

Generally, the Mudrock Line is referred to as being:

$$
\mathrm{V}_{\mathrm{p}}=\mathrm{A} * \mathrm{~V}_{\mathrm{s}}+\mathrm{B}
$$

where $\mathrm{A}=0.807$ and $\mathrm{B}=1.600$ are constants specific to the study area in Niger Delta. In the absence of shearwave data, Equation (14) can be used to estimate the shear-wave velocity when P-wave velocity is available.

Figure 16 is Poisson's ratio- $V_{p}$ cross-plot while Figure $17-V_{p} / V_{s}-V_{p}$ cross-plot. Mudrock Line is also plotted using Poisson's ratio versus $\mathrm{P}$-wave velocity and $\mathrm{V}_{\mathrm{p}} / \mathrm{V}_{\mathrm{s}}$ ratio versus $\mathrm{P}$-wave velocity $\mathrm{V}_{\mathrm{p}}$ as shown in Figures 16 and 17 respectively. Notice that the plot of Poisson's ratio against $\mathrm{P}$-wave velocity (Figure 16) shows that the lowest Poisson's ratio is 0.1 . On the $\mathrm{V}_{\mathrm{p}} / \mathrm{V}_{\mathrm{s}}$ ratio against $\mathrm{P}$-wave velocity plot (Figure 17), the curve approaches 1.5 asymptotically. These values $\left(\sigma=0.1\right.$ and $\left.\mathrm{V}_{\mathrm{p}} / \mathrm{V}_{\mathrm{s}}=1.5\right)$ represent the "dry rock" value for a dry porous sandstone. Thus, the "mudrock line approaches the "dry rock" line as P-wave velocity increases.

Figure 18 shows $\mathrm{V}_{\mathrm{p}} / \mathrm{V}_{\mathrm{s}}$-depth cross-plot showing the plot of both $\mathrm{S}$-wave velocity and P-wave velocities against depth. This profile shows that $\mathrm{P}$-wave velocity is higher than $\mathrm{S}$-wave velocity but all in the increasing trend throughout the investigated depth, but an anomaly of the velocity trend was observed at depth range $1864 \mathrm{~m}$ to $2050 \mathrm{~m}$ indicated by the circle, which corresponds to the reservoir location in the subsurface as shown by Figure 4. Figure 18 shows the variation of $V_{p} / V_{s}$ ratio with depth. The $V_{p} / V_{s}$ ratio for the depth of investigation ranges from 2.17 to 3.18. the abnormally low $\mathrm{V}_{\mathrm{p}} / \mathrm{V}_{\mathrm{s}}$ ratio values less than 3.00 within the depth correspond to some of the sand lithology identified from the Gamma-ray log. This zone is indicated as probable hydrocarbon zone where $\mathrm{V}_{\mathrm{p}} / \mathrm{V}_{\mathrm{s}}$ ration ranges from 2.35 to 3.18. these values are consistent with the observations of Gardner and Harris [19] , Gregory [20], Hamilton [21], and Tatham [22]. The depth ranges between 1864 and 1933.

Figure 19 is a cross-plot of Poisson's ratio versus depth, showing the variation of Poisson's ratio with depth for the depth under investigation. It shows a decrease of in Poisson's ratio with depth. The abnormally low Poisson's ratio (kick) values (less than 0.40) at specific depth intervals correspond to some of the sand lithologies identified from Gamma-ray log. These low Poisson's ratio are indicated as the probable hydrocarbon zone. Poisson's ratio ranges from 0.365 to 0.390 for the depth ranges between 1864 and 1930 .

\section{CONCLUSION}

The analysis and interpretations of the obtained data suggests that lithology and depth of burial of a formation have significant influence on petrophysical characteristics of reservoir such as: acoustic velocities, attenuation of acoustic velocities, porosity, density, fluid content etc. These influence exerted on the acoustic 
velocities by lithology and depth of burial are underpinned by the unique elastic constants, and densities of the different lithological materials and their resultant porosities, which is associated with the overburden pressure and the compressibility of these different lithological materials. Porosity decreases with depth. The results of the analysis show that the reservoir is $66 \mathrm{~m}$ sandstone thick having average porosity 0.26 , density $2.21 \mathrm{~g} / \mathrm{cc}$, Poisson's ratio $0.40, \mathrm{~V}_{\mathrm{s}} 579.68 \mathrm{~m} / \mathrm{s}, \mathrm{V}_{\mathrm{p}} 2230 \mathrm{~m} / \mathrm{s}, \mathrm{V}_{\mathrm{p}} / \mathrm{V}_{\mathrm{s}} 2.55$, and GR 90API. Poisson's ratio of 0.40 and $\mathrm{V}_{\mathrm{s}}$ $579.68 \mathrm{~m} / \mathrm{s}$ are indicative fluid-filled reservoir.

\section{TABLES AND FigureS}

Table 1: Independent variables - parameters digitized from the logs

\begin{tabular}{|c|c|c|c|c|c|c|c|}
\hline $\begin{array}{c}\text { Depth } \\
(\mathrm{m})\end{array}$ & $\begin{array}{c}\mathrm{V}_{\mathrm{p}} \\
(\mathrm{m} / \mathrm{s})\end{array}$ & $\rho\left(\mathrm{g} / \mathrm{cm}^{3}\right)$ & $\sigma$ (Poisson's ratio) & GR (API) & Porosity $(\phi)$ & Vs $(\mathrm{m} / \mathrm{s})$ & $\mathrm{V}_{\mathrm{p}} / \mathrm{V}_{\mathrm{s}}$ \\
\hline 1637 & 1985 & 2.03 & 0.46 & 95 & 0.38 & 508 & 3.91 \\
\hline 1647 & 2030 & 2.10 & 0.46 & 96 & 0.33 & 519 & 3.91 \\
\hline 1657 & 2030 & 2.10 & 0.46 & 96 & 0.33 & 519 & 3.91 \\
\hline 1667 & 2015 & 2.05 & 0.46 & 97 & 0.36 & 515 & 3.91 \\
\hline 1677 & 2015 & 2.05 & 0.46 & 97 & 0.36 & 515 & 3.91 \\
\hline 1687 & 1980 & 2.02 & 0.46 & 94 & 0.38 & 506 & 3.91 \\
\hline 1697 & 1980 & 2.04 & 0.46 & 97 & 0.37 & 539 & 3.67 \\
\hline 1707 & 2015 & 2.06 & 0.46 & 102 & 0.36 & 515 & 3.91 \\
\hline 1717 & 2015 & 2.06 & 0.46 & 102 & 0.36 & 515 & 3.91 \\
\hline 1728 & 2150 & 2.12 & 0.45 & 103 & 0.32 & 648 & 3.32 \\
\hline 1739 & 2050 & 2.07 & 0.45 & 98 & 0.35 & 589 & 3.48 \\
\hline 1750 & 2100 & 2.12 & 0.45 & 98 & 0.32 & 603 & 3.48 \\
\hline 1760 & 2170 & 2.09 & 0.45 & 97 & 0.34 & 624 & 3.48 \\
\hline 1770 & 2040 & 2.09 & 0.45 & 96 & 0.34 & 586 & 3.48 \\
\hline 1780 & 2040 & 2.09 & 0.45 & 96 & 0.34 & 586 & 3.48 \\
\hline 1790 & 2055 & 2.12 & 0.45 & 99 & 0.32 & 590 & 3.48 \\
\hline 1801 & 2055 & 2.12 & 0.45 & 99 & 0.32 & 590 & 3.48 \\
\hline 1811 & 2055 & 2.12 & 0.45 & 99 & 0.32 & 590 & 3.48 \\
\hline 1821 & 2100 & 2.12 & 0.45 & 100 & 0.32 & 603 & 3.48 \\
\hline 1832 & 2270 & 2.18 & 0.43 & 107 & 0.28 & 795 & 2.85 \\
\hline 1843 & 2128 & 2.14 & 0.45 & 102 & 0.31 & 642 & 3.32 \\
\hline 1855 & 2175 & 2.12 & 0.45 & 102 & 0.32 & 656 & 3.32 \\
\hline 1866 & 2570 & 2.3 & 0.39 & 101 & 0.21 & 1091 & 2.35 \\
\hline 1878 & 2230 & 2.28 & 0.43 & 98 & 0.22 & 756 & 2.95 \\
\hline 1889 & 2110 & 2.01 & 0.32 & 62 & 0.39 & 1074 & 1.96 \\
\hline 1921 & 2380 & 2.22 & 0.36 & 85 & 0.26 & 1097 & 2.17 \\
\hline 1933 & 2280 & 2.23 & 0.44 & 90 & 0.25 & 718 & 3.18 \\
\hline 1945 & 2310 & 2.23 & 0.42 & 105 & 0.25 & 858 & 2.69 \\
\hline 1956 & 2310 & 2.28 & 0.42 & 107 & 0.22 & 834 & 2.77 \\
\hline 1968 & 2480 & 2.30 & 0.40 & 105 & 0.21 & 1012 & 2.45 \\
\hline 1980 & 2430 & 2.17 & 0.37 & 110 & 0.29 & 1087 & 2.24 \\
\hline 1991 & 2180 & 2.14 & 0.44 & 100 & 0.31 & 686 & 3.18 \\
\hline 2014 & 2340 & 2.12 & 0.41 & 107 & 0.32 & 914 & 2.56 \\
\hline 2025 & 2270 & 2.19 & 0.42 & 104 & 0.28 & 843 & 2.69 \\
\hline 2038 & 2460 & 2.32 & 0.38 & 105 & 0.20 & 1082 & 2.27 \\
\hline 2050 & 2290 & 2.09 & 0.41 & 109 & 0.34 & 873 & 2.62 \\
\hline 2062 & 2290 & 2.09 & 0.41 & 109 & 0.34 & 873 & 2.62 \\
\hline 2073 & 2370 & 2.11 & 0.41 & 110 & 0.33 & 903 & 2.62 \\
\hline 2085 & 2215 & 2.19 & 0.43 & 103 & 0.28 & 776 & 2.85 \\
\hline 2096 & 2285 & 2.16 & 0.41 & 107 & 0.30 & 892 & 2.56 \\
\hline 2108 & 2400 & 2.16 & 0.39 & 112 & 0.30 & 1019 & 2.35 \\
\hline 2119 & 2250 & 2.12 & 0.41 & 111 & 0.32 & 858 & 2.62 \\
\hline 2131 & 2340 & 2.07 & 0.41 & 114 & 0.35 & 914 & 2.56 \\
\hline 2143 & 2250 & 2.10 & 0.41 & 107 & 0.33 & 845 & 2.66 \\
\hline
\end{tabular}


Petrophysical characteristics of Coastal Swamp Depobelt reservoir in the Niger Delta using well-log data

Table 1 continues

\begin{tabular}{|c|c|c|c|c|c|c|c|}
\hline $\begin{array}{c}\text { Depth } \\
\text { (m) }\end{array}$ & $\begin{array}{l}\text { Resistivity } \\
\quad(\Omega \mathrm{m})\end{array}$ & $\begin{array}{l}\text { Density } \\
\left(\mathrm{g} / \mathrm{cm}^{3}\right)\end{array}$ & $\begin{array}{c}\text { Formation } \\
\text { factor, } \mathrm{F}\end{array}$ & $\begin{array}{c}\text { Permeability, K } \\
\text { (md) }\end{array}$ & $\begin{array}{c}\text { Water } \\
\text { resistivity, } \mathrm{R}_{\mathrm{w}} \\
(\Omega \mathrm{m}) \\
\end{array}$ & $\begin{array}{c}\text { Water } \\
\text { saturation, } S_{w} \\
\end{array}$ & $\begin{array}{c}\text { Hydrocarbon } \\
\text { saturation, } \mathrm{S}_{\mathrm{HC}}\end{array}$ \\
\hline 1637 & 12.5 & 2.03 & 11.21 & 13260.40 & 0.72 & 0.80 & 0.19 \\
\hline 1647 & 9.3 & 2.1 & 13.11 & 6552.53 & 0.44 & 0.79 & 0.20 \\
\hline 1657 & 8.2 & 2.1 & 13.11 & 6552.53 & 0.39 & 0.79 & 0.20 \\
\hline 1667 & 10 & 2.05 & 11.69 & 10932.07 & 0.54 & 0.80 & 0.19 \\
\hline 1677 & 10.5 & 2.05 & 11.69 & 10932.07 & 0.57 & 0.80 & 0.19 \\
\hline 1687 & 9.5 & 2.02 & 10.97 & 14571.04 & 0.56 & 0.80 & 0.19 \\
\hline 1697 & 7.3 & 2.04 & 11.45 & 12049.47 & 0.41 & 0.80 & 0.19 \\
\hline 1707 & 10.5 & 2.06 & 11.96 & 9902.36 & 0.56 & 0.80 & 0.19 \\
\hline 1717 & 9.5 & 2.06 & 11.95 & 9902.36 & 0.50 & 0.80 & 0.19 \\
\hline 1728 & 9.5 & 2.12 & 13.75 & 5270.84 & 0.43 & 0.79 & 0.20 \\
\hline 1739 & 8 & 2.07 & 12.23 & 8954.74 & 0.41 & 0.79 & 0.20 \\
\hline 1750 & 8.4 & 2.12 & 13.76 & 5270.84 & 0.38 & 0.79 & 0.20 \\
\hline 1760 & 7 & 2.09 & 12.80 & 7284.75 & 0.34 & 0.79 & 0.20 \\
\hline 1770 & 5.2 & 2.09 & 12.80 & 7284.75 & 0.25 & 0.79 & 0.20 \\
\hline 1780 & 10.5 & 2.09 & 12.80 & 7284.75 & 0.52 & 0.79 & 0.20 \\
\hline 1790 & 8.3 & 2.12 & 13.75 & 5270.84 & 0.37 & 0.79 & 0.20 \\
\hline 1801 & 10.5 & 2.12 & 13.75 & 5270.84 & 0.48 & 0.79 & 0.20 \\
\hline 1811 & 9.9 & 2.12 & 13.75 & 5270.84 & 0.45 & 0.79 & 0.20 \\
\hline 1821 & 7.9 & 2.12 & 13.75 & 5270.84 & 0.36 & 0.79 & 0.20 \\
\hline 1832 & 8.1 & 2.18 & 16.08 & 2604.54 & 0.31 & 0.78 & 0.21 \\
\hline 1843 & 8.8 & 2.14 & 14.46 & 4205.17 & 0.38 & 0.79 & 0.20 \\
\hline 1855 & 8.4 & 2.12 & 13.75 & 5270.84 & 0.38 & 0.79 & 0.20 \\
\hline 1866 & 14.5 & 2.3 & 23.58 & 465.55 & 0.36 & 0.76 & 0.23 \\
\hline 1878 & 8 & 2.28 & 21.95 & 643.44 & 0.21 & 0.76 & 0.23 \\
\hline 1889 & 6 & 2.01 & 10.74 & 15987.85 & 0.36 & 0.80 & 0.19 \\
\hline 1921 & 7.4 & 2.22 & 18.06 & 1547.27 & 0.24 & 0.77 & 0.22 \\
\hline 1933 & 8 & 2.23 & 19.12 & 1197.95 & 0.25 & 0.77 & 0.22 \\
\hline 1945 & 16.5 & 2.23 & 19.12 & 1197.95 & 0.52 & 0.77 & 0.22 \\
\hline 1956 & 10.5 & 2.28 & 22.63 & 561.02 & 0.27 & 0.76 & 0.23 \\
\hline 1968 & 8 & 2.3 & 24.36 & 402.29 & 0.19 & 0.76 & 0.23 \\
\hline 1980 & 3.4 & 2.17 & 16.01 & 2663.92 & 0.13 & 0.78 & 0.21 \\
\hline 1991 & 6.3 & 2.14 & 14.76 & 3829.13 & 0.26 & 0.78 & 0.21 \\
\hline 2014 & 19.3 & 2.12 & 14.03 & 4820.41 & 0.86 & 0.79 & 0.20 \\
\hline 2025 & 19.8 & 2.19 & 16.94 & 2064.90 & 0.71 & 0.78 & 0.21 \\
\hline 2038 & 14.9 & 2.32 & 26.34 & 282.87 & 0.32 & 0.76 & 0.23 \\
\hline 2050 & 13.1 & 2.09 & 13.04 & 6701.91 & 0.63 & 0.79 & 0.20 \\
\hline 2062 & 12.8 & 2.09 & 13.04 & 6701.91 & 0.62 & 0.79 & 0.20 \\
\hline 2073 & 9.7 & 2.11 & 13.68 & 5391.01 & 0.44 & 0.79 & 0.20 \\
\hline 2085 & 9.8 & 2.19 & 16.94 & 2064.90 & 0.35 & 0.78 & 0.21 \\
\hline 2096 & 11.9 & 2.16 & 15.57 & 3013.81 & 0.47 & 0.78 & 0.21 \\
\hline 2108 & 5.9 & 2.16 & 15.57 & 3013.81 & 0.23 & 0.78 & 0.21 \\
\hline 2119 & 6.8 & 2.12 & 14.03 & 4820.41 & 0.30 & 0.79 & 0.20 \\
\hline 2131 & 12 & 2.07 & 12.44 & 8268.18 & 0.61 & 0.79 & 0.20 \\
\hline 2143 & 6.7 & 2.1 & 13.35 & 6016.78 & 0.31 & 0.79 & 0.20 \\
\hline
\end{tabular}


Table 2: Summary of the results of reservoir parameters

\begin{tabular}{|c|c|c|c|}
\hline \multicolumn{4}{|c|}{ TOP OF RESERVOIR } \\
\hline Porosity, $\phi$ & $\begin{array}{c}\text { Shear velocity, } \\
V_{\mathrm{s}}(\mathrm{m} / \mathrm{s})\end{array}$ & $\begin{array}{c}\text { Compressional velocity, } \\
V_{\mathrm{p}}(\mathrm{m} / \mathrm{s})\end{array}$ & $\mathrm{V}_{\mathrm{p}} / \mathrm{V}_{\mathrm{s}}$ \\
\hline $0.28-0.38$ & $508-795$ & $1980-2270$ & $3.32-3.91$ \\
\hline $\bar{\phi}=0.34$ & $\bar{V}_{s}=579.68$ & $\bar{V}_{p}=2066.1$ & $\bar{V}_{p} / \bar{V}_{s}=3.59$ \\
\hline \multicolumn{4}{|c|}{ RESERVOIR } \\
\hline $0.21-0.39$ & $718-1097$ & $2110-2570$ & $1.96-3.18$ \\
\hline $\bar{\phi}=0.26$ & $\bar{V}_{s}=932.33$ & $\bar{V}_{p}=2230$ & $\bar{V}_{p} / \bar{V}_{s}=2.55$ \\
\hline $0.20-0.35$ & $686-1087$ & $2180-2480$ & $2.24-2.85$ \\
\hline $\bar{\phi}=0.30$ & $\bar{V}_{s}=900.69$ & $\bar{V}_{p}=2322.50$ & $\bar{V}_{p} / \bar{V}_{s}=2.60$ \\
\hline
\end{tabular}

Table 2 continues

\begin{tabular}{|c|l|l|}
\hline \multicolumn{3}{|c|}{ TOP OF RESERVOIR } \\
\hline Density, $\rho$ & Poisson's ratio, $\sigma$ & \multicolumn{1}{c|}{ GR (API) } \\
\hline $2.02-2.18$ & $0.43-0.47$ & $95-103$ \\
$\bar{\rho}=2.09$ & $\bar{\sigma}=0.46$ & $\bar{G} \bar{R}=98.73$ \\
\hline \multicolumn{3}{|c|}{ RESERVOIR } \\
\hline $2.01-2.30$ & $0.33-0.45$ & $62-105$ \\
$\bar{\rho}=2.21$ & $\bar{\sigma}=0.40$ & $\bar{G} \bar{R}=90$ \\
\hline \multicolumn{3}{|c|}{ BOTTOM OF RESERVOIR } \\
\hline $2.07-2.32$ & $0.39-0.45$ & $103-114$ \\
$\bar{\rho}=2.16$ & $\bar{\sigma}=0.41$ & $\bar{G} \bar{R}=108$ \\
\hline
\end{tabular}

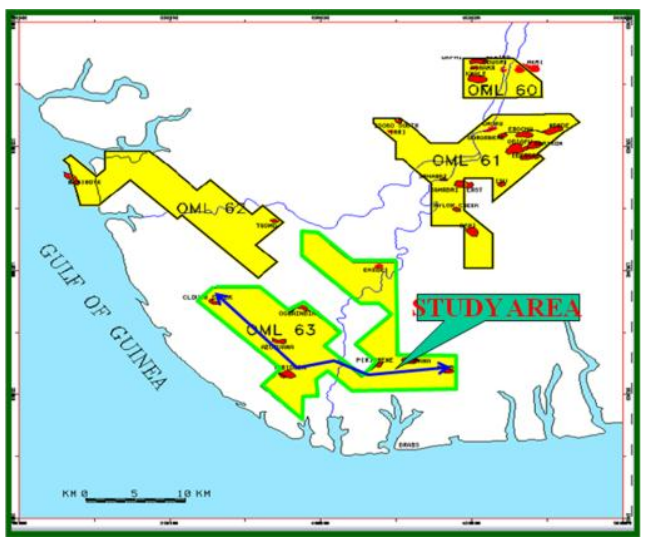

Figure 1: Map of the Niger Delta showing area of study

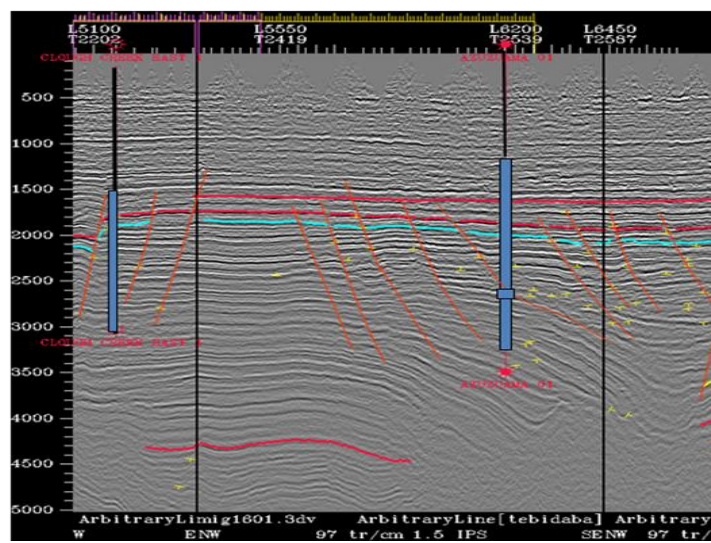

Figure 2: The structure of the study area

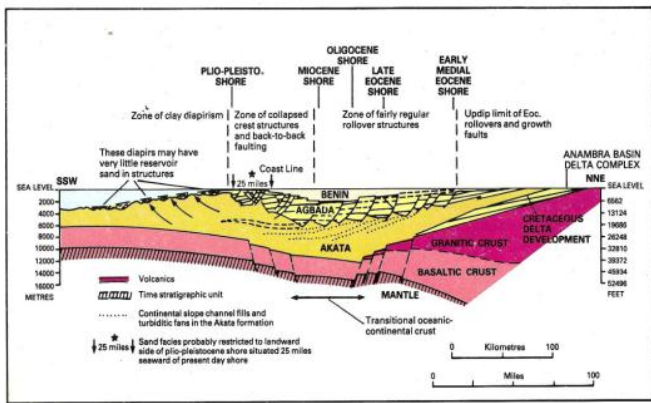

Fig. 3: Structural section of the Niger Delta Complex showing Benin, Agbada and Akata formations (Short and Stauble, 1967) 


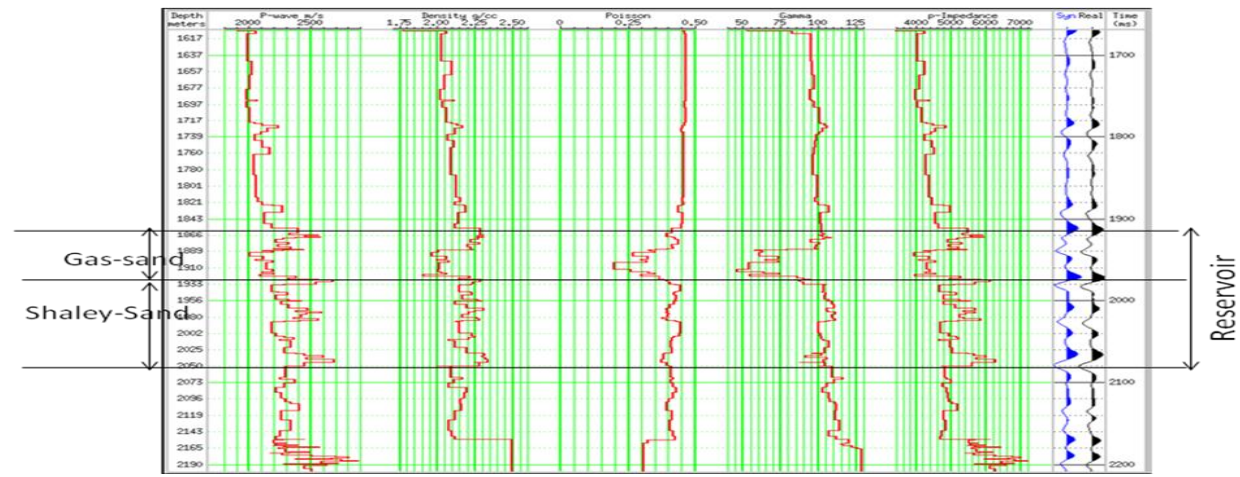

Figure 4: Synthetic seismogram generated for calibration

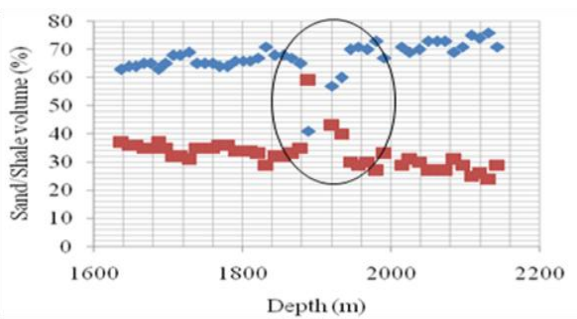

Fig. 5: Sand/shale-depth cross-plot
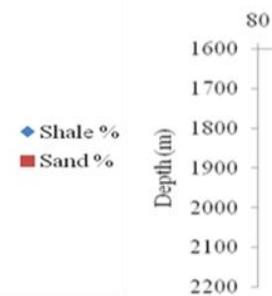

2200

Fig. 6: Gamma-ray API-depth cross-plot

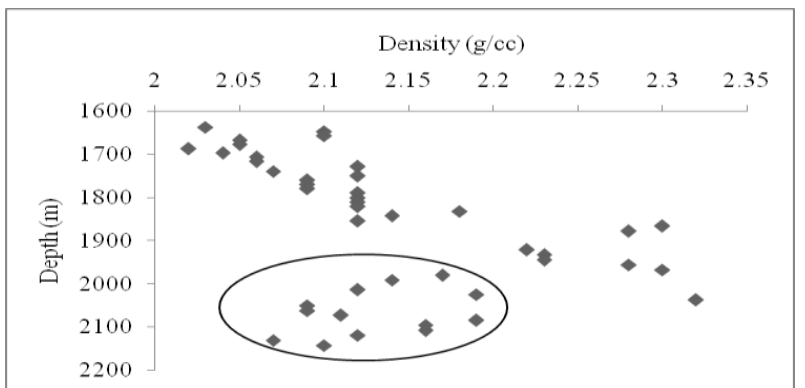

Fig. 7: Density-depth cross-plot

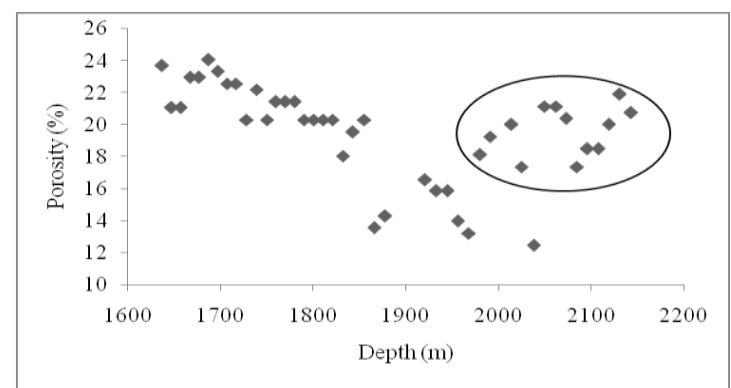

Fig. 8: Depth-porosity cross-plot

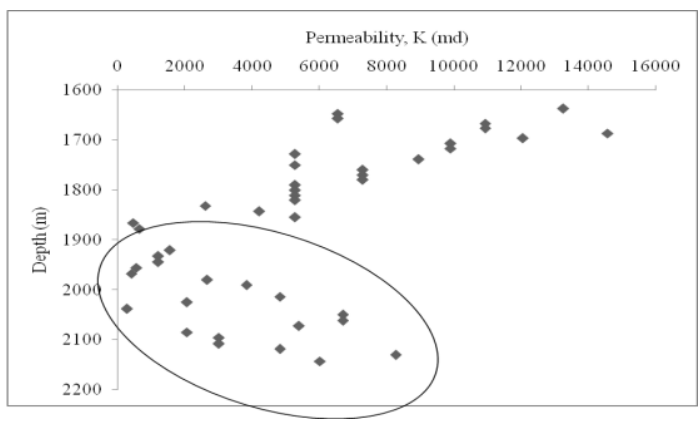

Fig. 9: Depth-permeability cross-plot

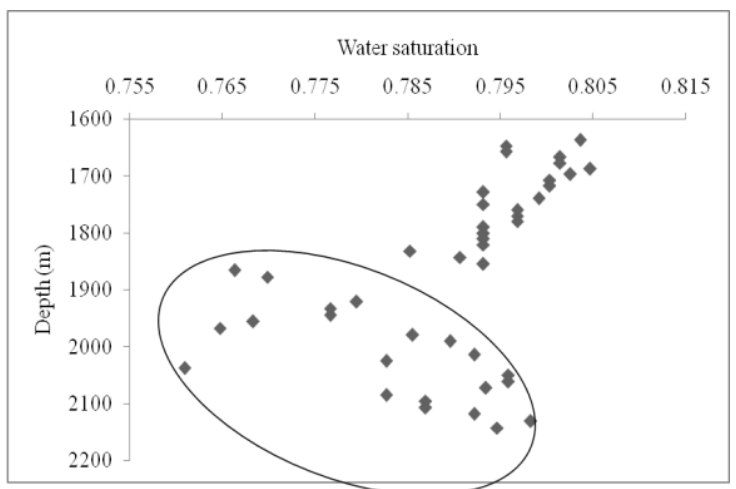

Fig. 11: Depth-water saturation cross-plot

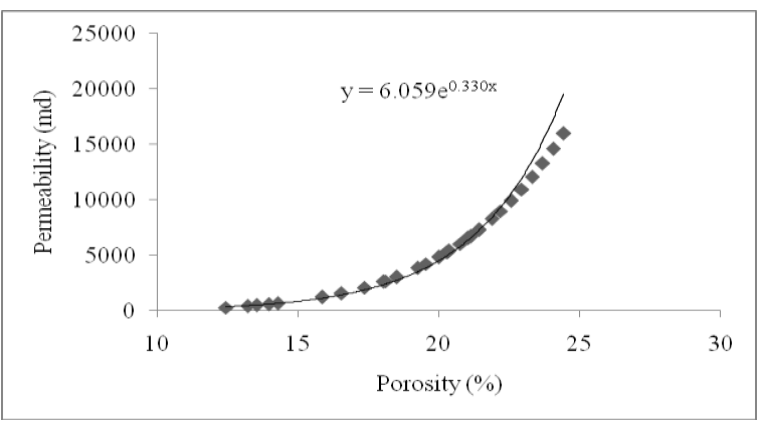

Fig. 10: Permeability-porosity cross-plot

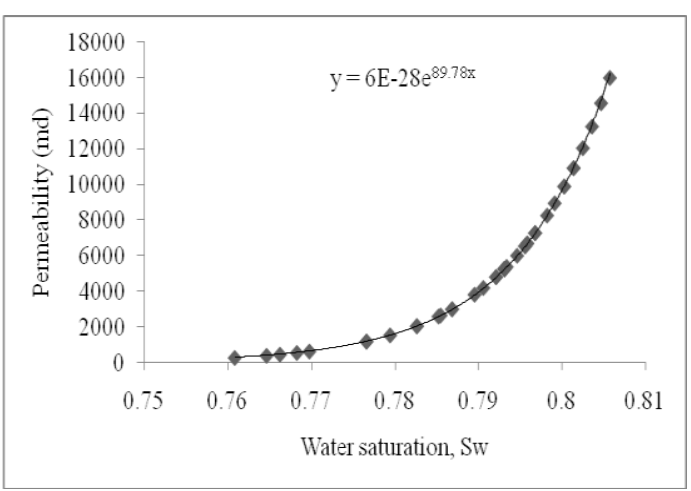

Fig. 12: Permeability-water saturation cross-plot 


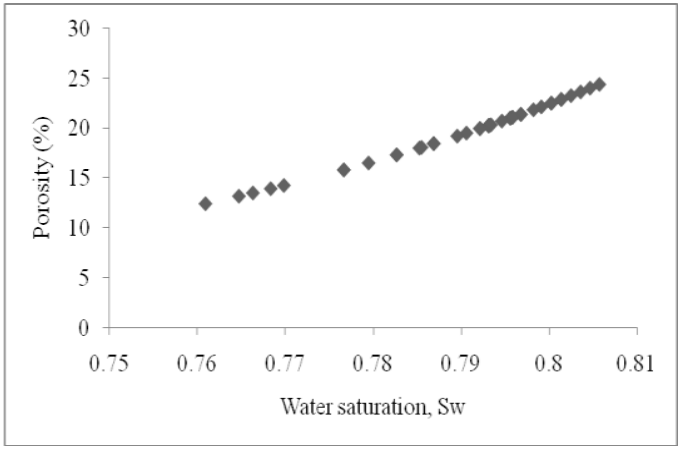

Fig. 13: Porosity-water saturation cross-plot

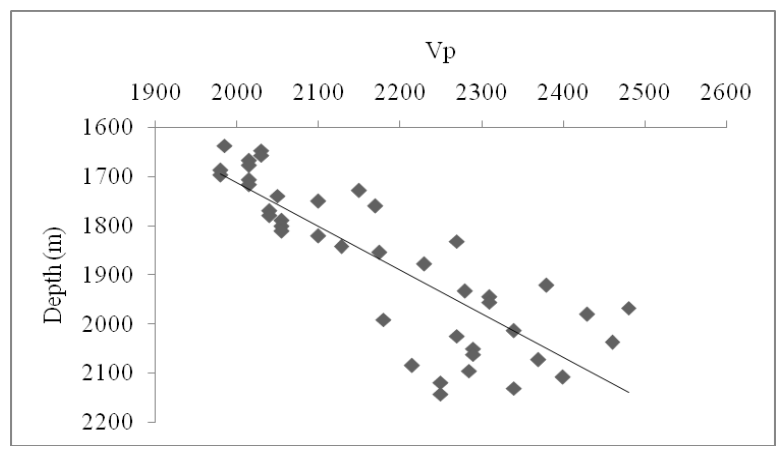

Fig. 14: $\mathrm{V}_{\mathrm{p}}$-Depth cross-plot

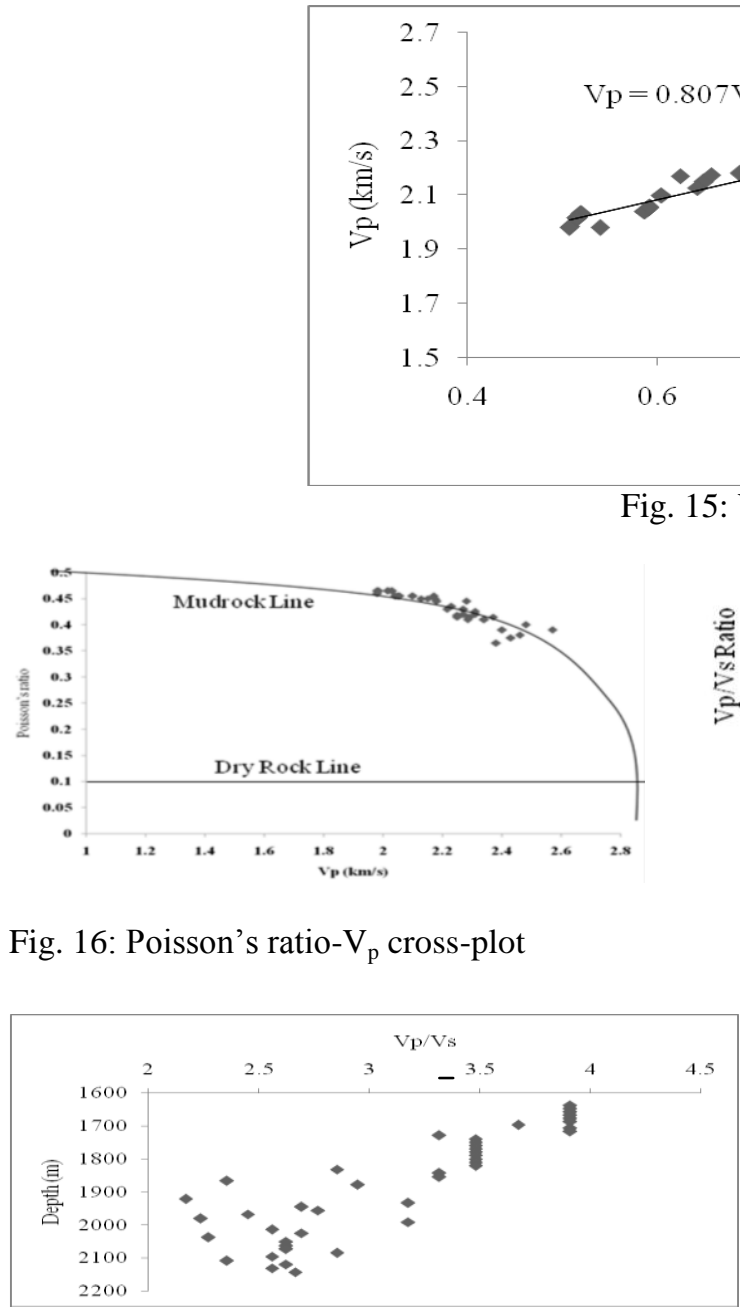

Fig. 18: Vp/Vs-Depth cross-plot

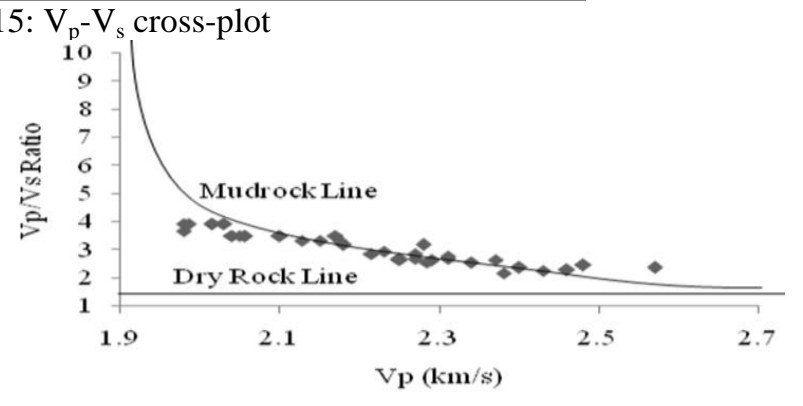

Fig. 17: $\mathrm{V}_{\mathrm{p}} / \mathrm{V}_{\mathrm{s}}$ ratio- $\mathrm{Vp}$ cross-plot

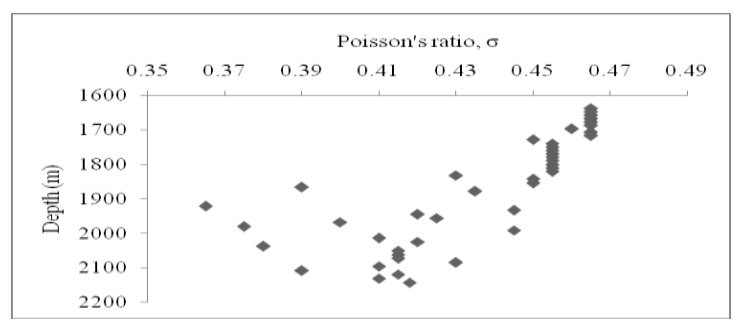

Fig. 19: Poisson's Raio-depth cross-plot

\section{CONCLUSION}

The analysis and interpretations of the obtained data suggests that lithology and depth of burial of a formation have significant influence on petrophysical characteristics of reservoir such as: acoustic velocities, attenuation of acoustic velocities, porosity, density, fluid content etc. These influence exerted on the acoustic velocities by lithology and depth of burial are underpinned by the unique elastic constants, and densities of the different lithological materials and their resultant porosities, which is associated with the overburden pressure and the compressibility of these different lithological materials. Porosity decreases with depth. The results of the analysis show that the reservoir is $66 \mathrm{~m}$ sandstone thick having average porosity 0.26 , density $2.21 \mathrm{~g} / \mathrm{cc}$, Poisson's ratio 0.40, $\mathrm{V}_{\mathrm{s}} 579.68 \mathrm{~m} / \mathrm{s}, \mathrm{V}_{\mathrm{p}} 2230 \mathrm{~m} / \mathrm{s}, \mathrm{V}_{\mathrm{p}} / \mathrm{V}_{\mathrm{s}} 2.55$, and GR 90API. Poisson's ratio of 0.40 and $\mathrm{V}_{\mathrm{s}}$ $579.68 \mathrm{~m} / \mathrm{s}$ are indicative fluid-filled reservoir. 


\section{Acknowledgements}

The authors are grateful to Nigerian National Petroleum Corporation (NNPC) for provision of the necessary data, and to China University of Geosciences (Wuhan) for data analysis.

\section{REFERENCES}

[1] K. C. Short, and A. J. Stauble, Outline of geology of Niger Delta. American Association of Petroleum Geologists Bulletin, 51, 1967, 761-779.

[2] J. E. Ejedawe, Patterns of incidence of oil reserves in Niger Delta Basin. American Association of Petroleum Geologists, 65, 1981, 1574-1585.

[3] B. D. Evamy, J. Haremboure, P. Kamerling, W. A. Knaap, F. A. Molloy, and P. H. Rowlands, Hydrocarbon habitat of Tertiary Niger Delta, American Association of Petroleum Geologists Bulletin, 62, 1978, 277-298.

[4] H. Doust and E. Omatsola, Niger Delta, in, Edwards, J. D., and Santogrossi, P.A., eds., Divergent/passive Margin Basins, AAPG Memoir 48: Tulsa, American Association of Petroleum Geologists, 1990, 239-248.

[5] Schlumberger, Log interpretation: Principles/Applications (Schlumberger educational series, USA, 1987).

[6] M. Rider, The geological interpretation of well logs (Progress Press Co. Ltd, Malta, 2006).

[7] J. E. Calderon and J. Castagna (Porosity and lithologic estimation using rock physics and multi-attribute transforms in Balcon Field, Colombia. 2007), 142 - 150.

[8] D. R. Issler, A new approach to shale compaction and stratigraphic restoration, Beaufort-Mackenzie Basin and Mackenzie Corridor, northern Canada, American Association of Petroleum Geologists Bulletin, 76 (8), 1992, 1170-1189.

[9] O. I. Horsfall, E. D. Uko and I. Tamunobereton-ari, Comparative analysis of sonic and neutron-density logs for porosity determination in the South-eastern Niger Delta Basin, Nigeria, American Journal of Scientific and Industrial Research, 4(3), 2013. 261-271.

[10] M. J. Wyllie, G. Gregory, and H. F. Gardner, Experimental investigation of factors affecting elastic wave velocity in porous media, Geophysics, 23, 1958, 459-493.

[11] Z. Wang, Fundamentals of Seismic Rock Physics, Geophysics 66 (2), 2001, 398 - 412

[12] J. E. Carothers, A statistical study of the formation factor relation to porosity, The Log Analyst, 9, 1958,38 - 52.

[13] R. R. Berg, Method for determining permeability from reservoir rock properties: Transactions, Gulf Coast Association of geological Societies, 20, 1970, $303-317$.

[14] J. Finol and X. D. Jing, Permeability prediction in shaly formations: The fuzzy modeling approach, Geophysics, 67 (3), $2002,817-$ 829.

[15] G. Asquith and D. Krygowski, Basic Well Log Analysis, American Association of Petroleum Geologists Methods in Exploration Series, 2004, No 16.

[16] E. J. Frankl, and E. A. Cordy, The Niger Delta Oil Province: Recent developments onshore and offshore, Proceedings of Seventh World Petroleum Congress, Mexico City, 1967, 195-209.

[17] G. E. Archie, The Electrical Resistivity as an Aid in Determining Some Reservoir Characteristics, Journal of Petroleum Technology, 5, 1942, 54-62.

[18] J. P. Castagna, M. L. Batzle, and R. L. Eastwood, Relationships between compressional-wave and shear-wave velocities in clastic silicate rocks, Geophysics, 50, 1985, 571-581.

[19] G. H. F. Gardner and M. H. Harris, Velocity and attenuation of elastic waves in sands, SPWLA Ninth Annual Logging Symposium, 1 - 18, 1968.

[20] A. R. Gregory, Fluid saturation effects on dynamic elastic properties of sedimentary rocks, Geophysics, 41, 1977,895 - 921.

[21] E. L. Hamilton, Elastic properties of marine sediments: J. Geophys. Res., 76, 1971, 579 - 604.

[22] R. H. Tatham, $\mathrm{V}_{\mathrm{p}} / \mathrm{V}_{\mathrm{s}}$ and lithology, Geophysics, 47, 1982, $336-344$. 